\title{
Nanostructuring carbon supports for optimal electrode performance in biofuel cells and hybrid fuel cells
}

\author{
Dominika Majdecka $^{1} \cdot$ Renata Bilewicz $^{1}$
}

Received: 11 May 2015 /Revised: 8 July 2015 / Accepted: 12 July 2015 / Published online: 26 July 2015

(C) The Author(s) 2015. This article is published with open access at Springerlink.com

\begin{abstract}
The efficiencies of dioxygen reduction on common carbonaceous materials were compared using voltammetry and fuel cell measurements. Carbon paper (CP), carbon fibre (CF) or carbon cloth (CC) conducting supports were covered under water pump pressure with multiwalled carbon nanotubes (MWCNTs) to increase the working surface of the electrode, improve connectivity with enzyme molecules and provide direct electron transfer. Laccase was the biocathode catalyst catalyzing 4-electron reduction of oxygen to water on the nanostructured electrode. CP carbon paper was selected as the favourable electrode substrate, since it provided best durability holding firmly the carbon nanotubes together with the enzyme at the electrode surface. Zinc disc or fructose dehydrogenase was used as anode in the hybrid fuel cell and biofuel cell, respectively. The characteristics under externally applied resistances and potential-time dependencies under flowing solution conditions were evaluated. The hybrid fuel cell based on $\mathrm{Zn}$ anode and $\mathrm{CP}$ supported laccase cathode gave the best results in terms of power and open circuit potential (OCP). The full biofuel cell based on laccase and fructose dehydrogenase shows lower OCP but the power-time dependencies were similar to those of the hybrid biofuel cell. The nanostructured surfaces show good supercapacitor properties due to the presence of carbon nanotubes at the electrode surface. The fuel cells undergo self-charging/discharging and, therefore, can be conveniently employed in pulsed-work regime to power external devices.
\end{abstract}

Devoted to Professor Jose Zagal on the occasion of his 65 birthday.

Renata Bilewicz

bilewicz@chem.uw.edu.pl

1 Faculty of Chemistry, University of Warsaw, Pasteura 1, 02-093 Warsaw, Poland
Keywords Oxygen reduction - Laccase $\cdot$ Hybrid fuel cell · Biofuel cell $\cdot$ Carbon nanotubes $\cdot$ Fructose dehydrogenase . Fuel cell $\cdot \mathrm{Zn}$ anode

\section{Introduction}

There have been several approaches in the recent years to substitute costly platinum electrodes in the fuel cells with non-precious metal catalysts and carbon materials such as graphite electrodes or carbon electrodes covered with carbon nanoparticles or carbon nanotubes. Several transition M-N4 metal compounds have been proposed as catalytic materials for the oxygen reduction reaction (ORR). The catalytic materials include macrocyclic metal complexes with phthalocyanine or porphyrin ligands [1-5]. These complexes show high catalytic activity but show low stability in the corrosive environment of fuel cells. However, thermal treatment at ca. $1000^{\circ} \mathrm{C}$ or more of mixtures of these complexes with carbon powders increases activity and stability of the catalyst $[6,7]$. The M-N4 type moiety obtained in result of pyrolysis has been identified as the active catalytic site for oxygen reduction. While several difficulties connected with the use of Pt can be eliminated, the process of oxygen reduction on such materials is usually a $2 \mathrm{e}$ electrode process and not the favourable $4 \mathrm{e}$ reduction leading directly to water. On the other hand, multicopper oxidases such as laccase or bilirubin oxidase efficiently convert oxygen to water in a $4 \mathrm{e}$ transfer mechanism without the formation of toxic oxygen intermediates, e.g. superoxides or peroxides [8-14]. The difficulty with these redox enzyme applications is that usually an electron mediator is needed to allow electron transfer between the electrode and the active site of the enzyme [15-18]. Mediators may lead to unwanted reactions or leach to the solution, and if coimmobilized with the enzyme, they may not be sufficiently 


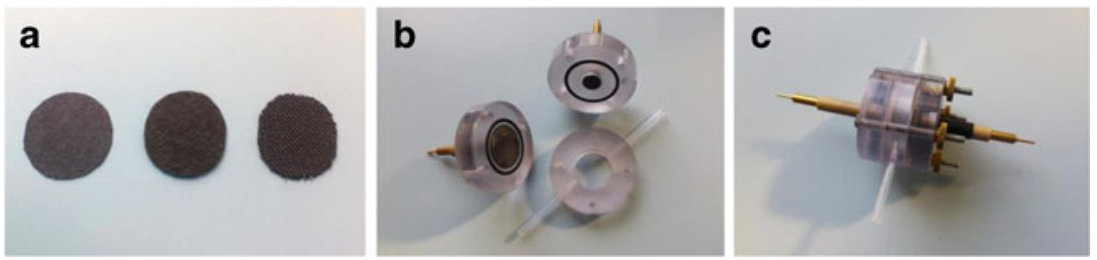

Fig. 1 (a) Carbon paper, carbon fibre and carbon cloth electrode substrates before modification with MWCNTs. (b) Cathode, anode contact and reaction compartment of the cell. (c) Fuel cell assembly working under flow conditions

active anymore. To remove the need of mediators and to find the optimal way of enzyme immobilization at the electrode surface have been major goals of recent work in this area [19-23]. The carbon nanoparticles, e.g. carbon nanotubes become helpful in this case since they improve the contact between the enzyme active site and electrode and they promote direct electron transfer (DET) of electrons to the conducting support [24-35]. In addition, carbon nanotubes at the carbon electrode form a nanocomposite electrode showing supercapacitor properties. Such combination of enzymatic catalysis with charge storing matrix would improve the performance of the electrodes and provide more efficient powering abilities in a biofuel cell arrangement [36-40].

In the present paper, we compare the performances of various carbon substrates covered with multiwalled carbon nanotubes and laccase in the catalytic reduction of oxygen. The carbon supports chosen allow to attach carbon nanotubes simply by sucking them under pressure of the water pump. We choose the best way of preparing bioelectrodes (electrode substrate, nanostructuring procedure, enzyme immobilization procedure) test several electrodes in the fuel cell arrangement — both in a hybrid fuel cell with $\mathrm{Zn}$ anode and enzymatic cathode, and in a fully enzymatic biofuel cell with fructose dehydrogenase acting as the anodic enzyme. We also underline the ease and short time of recovering the OCP, hence of regenerating the enzymatic fuel cells which makes them advantageous for powering long-term monitoring devices working in the on/off regime.

\section{Materials and chemicals}

Citric acid $\left(\mathrm{C}_{6} \mathrm{H}_{8} \mathrm{O}_{7}\right)$, disodium hydrogen phosphate $\left(\mathrm{Na}_{2} \mathrm{HPO}_{4}\right)$ and ethanol $\left(\mathrm{C}_{2} \mathrm{H}_{5} \mathrm{OH}\right)$ were purchased from POCh. Laccase Trametes versicolor was obtained from SigmaAldrich. The laccase activity dissolved in $1 \mathrm{ml}$ of water was $1360 \mathrm{Ug}^{-1}$. Fructose dehydrogenase (FDH) from Gluconobacter sp. was purchased from Sorachim. Multiwalled carbon nanotubes (MWCNTs Nanocyl Thin MWCNT $95+\% \mathrm{C}$ purity, $9.5 \mathrm{~nm}$ average diameter, $1.5 \mu \mathrm{m}$ length) were from Nanocyl, Belgium. Carbon paper (CP) was Toray Teflon Treated (TPG-H-030 Fuel Cell Store). Carbon fibre was received from the University of Reading, and carbon cloth (Wet Proofed) was from Fuel Cell Store. Water was distilled and passed through Milli-Q purification system.

\section{Electrochemical instrumentation and procedures}

Carbon paper (CP) and other carbon material supports were modified with MWCNTs under reduced pressure. MWCNTs suspension was obtained by adding 8 -mg nanotubes to $12-\mathrm{ml}$ ethanol (2 mg of MWCNTs for electrode unless otherwise stated). Electrode area was $3.14 \mathrm{~cm}^{2}$ (Fig. 1a).

Laccase was physically adsorbed on MWCNT covered electrode by incubation in $200 \mu \mathrm{l}$ of Mcllvaine buffer solution containing usually $25 \mathrm{mg} \mathrm{ml}^{-1}$ laccase. After 1 day of laccase adsorption, the electrode was washed thoroughly with water and used as a biocathode. Catalytic performance of each bioelectrode was evaluated by cyclic voltammetry in a threeelectrode arrangement with $\mathrm{Ag} / \mathrm{AgCl}$ ( $\mathrm{KCl}$ sat.) reference electrode, a platinum foil counter electrode and the MWCNT - nanostructured carbonaceous electrode as the working electrode. All electrochemical experiments were carried out using the Electrochemical Analyzer CHI 400 B potentiostat at $22 \pm$ $2{ }^{\circ} \mathrm{C}$.

The fuel cells: Zn anode-MWCNT cell, Zn hybrid fuel cell and biofuel cell were used under solution flow conditions (Fig. 1).

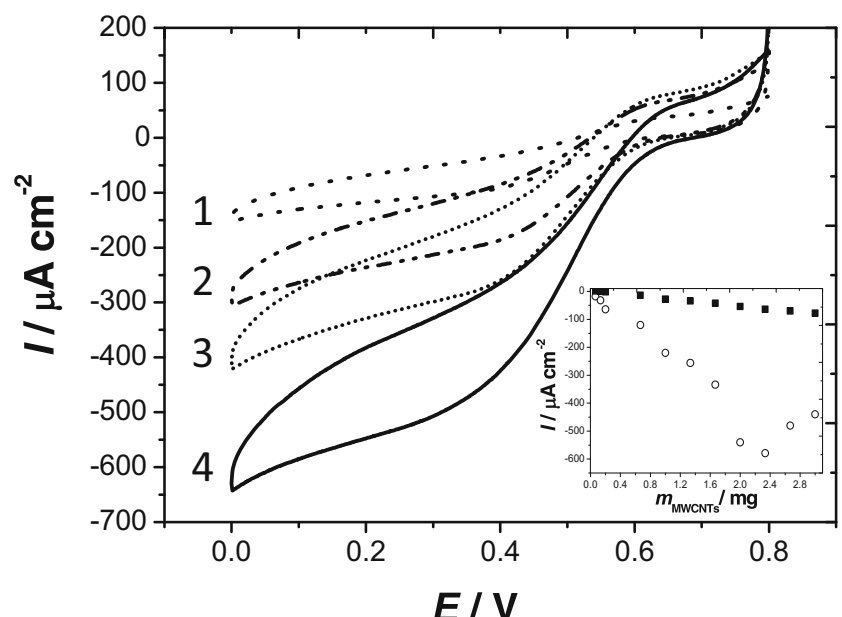

Fig. 2 Cyclic voltammograms recorded for catalytic oxygen reduction in oxygen saturated $0.1 \mathrm{M}$ Mcllvaine buffer solution $(\mathrm{pH} 5.3)$ using electrodes modified with (1) 0.67 , (2) 1.34 , (3) 1.66 and (4) $2 \mathrm{mg}$ of MWCNTs and laccase; scan rate $1 \mathrm{mV} \mathrm{s}^{-1}$. Inset: (circles) catalytic and (squares) background current densities of oxygen reduction on $\mathrm{CP}$ electrodes containing increasing mass of MWCNTs on the electrode surface. Laccase concentration was $25 \mathrm{mg} \mathrm{ml}^{-1}$ 
Zinc disc covered with zinc phosphate (hopeite) was used as the anode in the Zn hybrid fuel cell and fructose dehydrogenase (FDH) adsorbed on MWCNT - nanostructured support was the anode in the full biofuel cell. One hundred fifty microliters of $20 \mathrm{mg} \mathrm{ml}^{-1}$ FDH solution was used for modifying the electrode. Enzyme was applied and the electrode was kept in a fridge overnight to evaporate the solvent during the enzyme adsorption. Electrode contact was made of glassy carbon material. The cell arrangement cathode, anode and reaction compartment in between are shown in Fig. 1 b.

The open circuit voltage (OCV) was measured in all experiments. Voltages between anode and cathode were measured under loads changing in the range $10 \mathrm{M} \Omega$ to $1 \Omega$. To minimize the power loss caused by oxygen depletion, during testing of
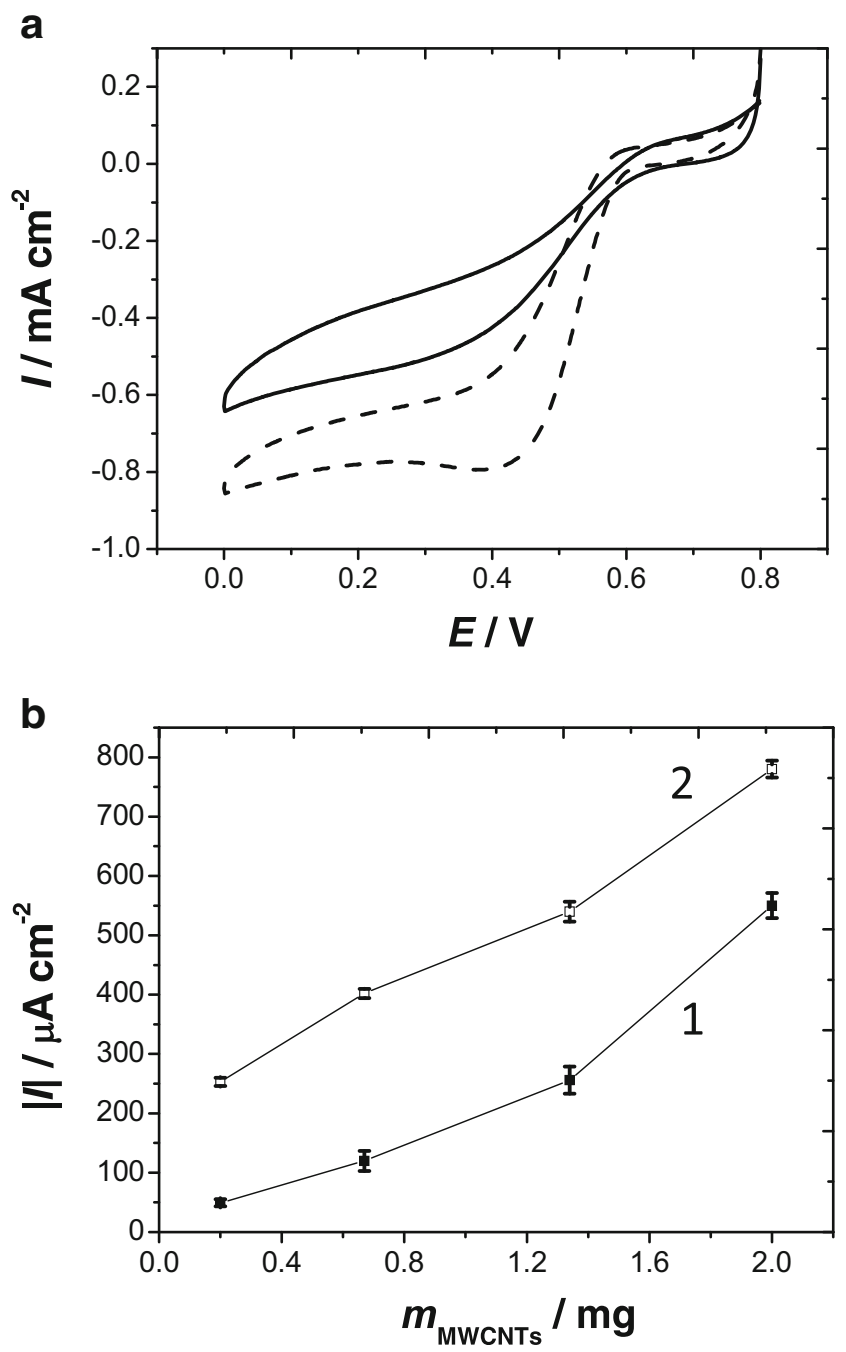

Fig. 3 (a) Cyclic voltammograms recorded for catalytic oxygen reduction using $\mathrm{CP}$ electrodes modified with $2 \mathrm{mg}$ MWCNTs and laccase adsorbed from two solutions: McIlvaine buffer solution $\mathrm{pH} 5.3$ (solid line) and same buffer-ethanol mixture, 1:1 (dashed line). (b) Current density values for $\mathrm{CP}$ electrodes covered with different volumes of MWCNTs and laccase adsorbed from buffer solution (1) and bufferethanol mixture (2). Experiments were conducted in $\mathrm{O}_{2}$ saturated solutions; scan rate $1 \mathrm{mV} \mathrm{s}^{-1}$. Laccase concentration was $25 \mathrm{mg} \mathrm{ml}^{-1}$ the cell measurements of power under each load were taken $5 \mathrm{~s}$ after the application of the resistance. Measurements were held always under $10 \mathrm{ml} \mathrm{min}^{-1}$ solution flow conditions.

\section{Results and discussion}

\section{Electrochemical studies}

The cyclic voltammograms of oxygen catalytic reduction on laccase and MWCNTs modified CP substrate are shown in Fig. 2. The biocathodes were modified with different volumes of MWCNTs suspension. The onset of catalytic current of oxygen reduction appears at potential ca. $+0.6 \mathrm{~V}$ (all potentials are vs. $\mathrm{Ag} / \mathrm{AgCl} / 1 \mathrm{M} \mathrm{KCl}_{\text {aq }}$ reference electrode). No mediators were needed to obtain a well-developed reduction curve. The optimal coverage of the electrode by carbon nanotubes was selected as shown in the inset of Fig. 2.

Figure 3 shows the plot of current density vs. mass of MWCNTs present at the CP electrode. The electrodes were covered with different volumes of MWCNT dispersion, and then the electrode was incubated in $25 \mathrm{mg} \mathrm{ml}^{-1}$ laccase solution-either buffer solution and buffer-ethanol mixture. It should be noted that the current density for a given mass of MWCNTs on the CP electrode is always larger when the buffer solution contains ethanol. The oxygen reduction currents achieve maximum values when ca. 2-2.4 mg of MWCNTs are present at the surface. Above this amount, the thickness of the nanotube layer becomes too large, and the catalytic current decreases. At larger amounts of MWCNTs, their release from the surface of the electrode to the solution can be detected when the cell is working at a longer time-scale; thus, also the durability of the electrode is affected.

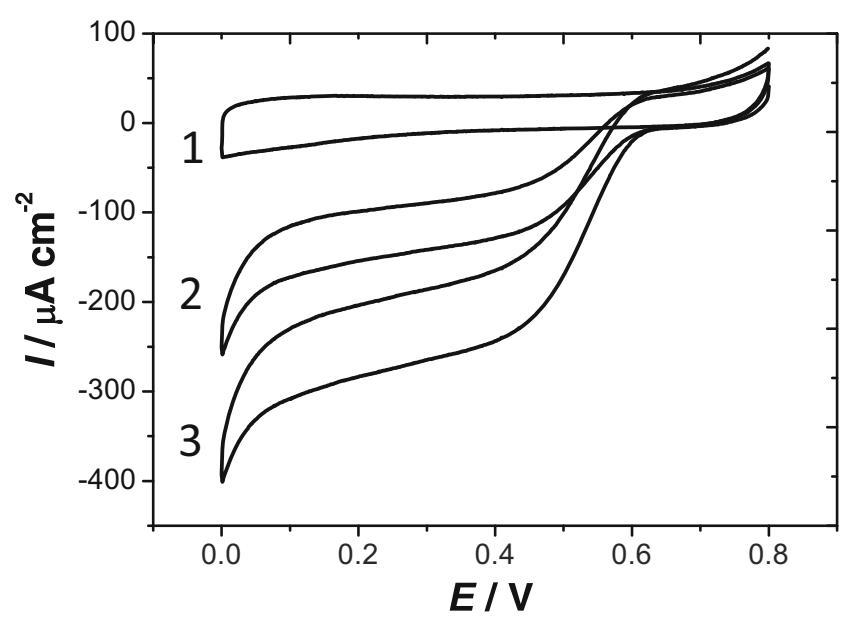

Fig. 4 Cyclic voltammograms recorded for catalytic oxygen reduction in oxygen saturated 0.1 M McIlvaine buffer solution (pH 5.3) using CP electrodes modified with $0.14 \mathrm{mg}$ MWCNTs (1) and MWCNTs with adsorbed laccase at concentration $12 \mathrm{mg} \mathrm{ml}^{-1}$ (2) and $25 \mathrm{mg} \mathrm{ml}^{-1}$ (3). Scan rate $5 \mathrm{mV} \mathrm{s}^{-1}$ 

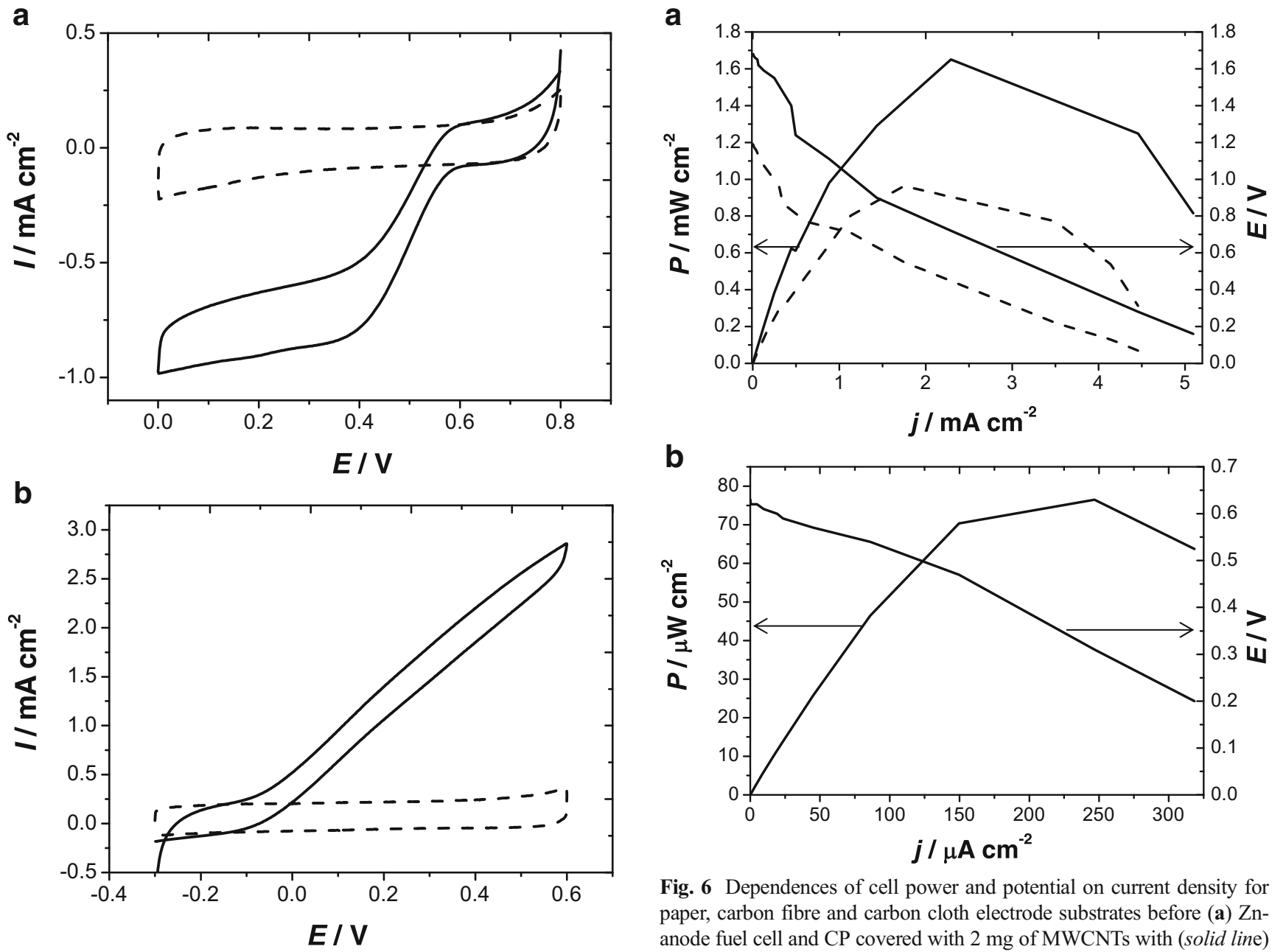

Fig. 6 Dependences of cell power and potential on current density for paper, carbon fibre and carbon cloth electrode substrates before (a) $\mathrm{Zn}$ anode fuel cell and CP covered with $2 \mathrm{mg}$ of MWCNTs with (solid line) and without laccase (dashed line), (b) laccase/FDH biofuel cell. Electrode area was $3.14 \mathrm{~cm}^{2}$. Experiments were done in (a) aerated McIlvaine buffer solution, pH 5.3 and (b) in the presence of $100 \mathrm{mM}$ fructose MWCNTs with laccase in oxygen (solid line) and deaerated (dashed line) condition and (b) CP covered with $2 \mathrm{mg}$ of MWCNTs with FDH with $100 \mathrm{mM}$ fructose (solid line) and without substrate (dashed line). McIlvaine buffer solution, $\mathrm{pH} 5.3$. Electrode area was $3.14 \mathrm{~cm}^{2}$, scan rate $5 \mathrm{mV} \mathrm{s}^{-1}$

As shown in Fig. 3a for a CP electrode covered with $2 \mathrm{mg}$ of MWCNTs, the adsorption of laccase from a solution containing McIlvaine buffer and ethanol 1:1 is much more efficient than from pure aqueous buffer. The catalytic wave is significantly larger and better developed.

Scheme 1 (A) Zn-MWCNTs cathode fuel cell, (B) Zn-hybrid fuel cell with laccase cathode and (C) full FDH/laccase biofuel cell
A

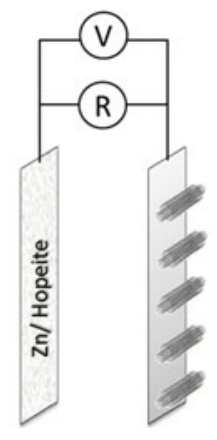

B

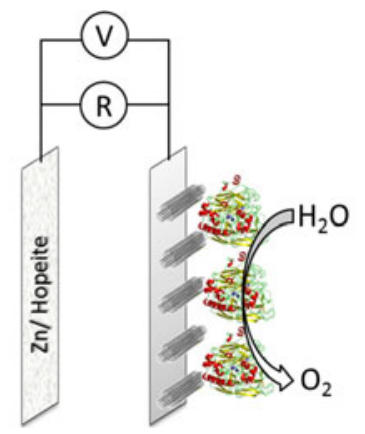

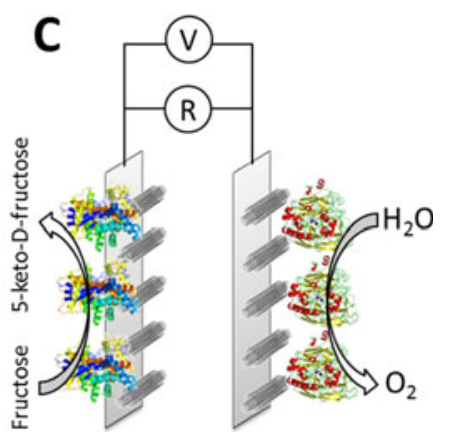


Table 1 Characteristics of $\mathrm{Zn}$ anode-MWCNTs cell and Zn anode-hybrid fuel cell for three types of carbon material support- $\mathrm{CP}, \mathrm{CF}$ and $\mathrm{CC}$ covered with $2 \mathrm{mg}$ of MWCNTs and adsorbed laccase

\begin{tabular}{lllll}
\hline Cathodes & Conducting support & $P_{\max } / \mathrm{mW} \mathrm{cm}^{-2}$ & $E_{\max } / \mathrm{V}^{\mathrm{a}}$ & $E_{\mathrm{OCV}} / \mathrm{V}$ \\
\hline Zn-hybrid fuel cell & CP & $1.65 \pm 0.21$ & $0.72 \pm 0.04$ & $1.70 \pm 0.03$ \\
& CF & $1.61 \pm 0.19$ & $0.71 \pm 0.03$ & $1.69 \pm 0.04$ \\
& CC & $1.47 \pm 0.13$ & $0.68 \pm 0.03$ & $1.73 \pm 0.04$ \\
Zn-MWCNTs fuel cell & CP & $0.96 \pm 0.12$ & $0.55 \pm 0.04$ & $1.22 \pm 0.04$ \\
& CF & $0.89 \pm 0.09$ & $0.53 \pm 0.02$ & $1.22 \pm 0.05$ \\
& CC & $1.07 \pm 0.1$ & $0.51 \pm 0.04$ & $1.25 \pm 0.03$ \\
\hline
\end{tabular}

Experiments were conducted in aerated Mcllvaine buffer solution, $\mathrm{pH} 5.3$

${ }^{a}$ Voltage at maximum power
Two types of anodes were employed: $\mathrm{Zn}$ electrode and the CP electrode covered with MWCNTs onto which FDH solution containing $20 \mathrm{mg} \mathrm{ml}^{-1}$ of enzyme was applied. The enzymatic electrode was kept in a fridge overnight to evaporate slowly the solvent applied during the enzyme adsorption. The cyclic voltammograms recorded for $\mathrm{CP}$ electrodes with fructose dehydrogenase and laccase are shown in Fig. 5. They visualize the difference in potentials of the electrodes in a fully enzymatic biofuel cell. CP electrodes are now covered with $2 \mathrm{mg}$ of MWCNTs and laccase adsorbed from buffer-ethanol solution containing $25 \mathrm{mg} \mathrm{ml}^{-1}$ of enzyme.

Figure $5 \mathrm{~b}$ shows that for $100 \mathrm{mM}$ fructose solution, the catalytic curve of fructose oxidation was observed at the potential ca. $-0.1 \mathrm{~V}$. The wave is better developed with larger slope for the cathode; however, it should be underlined that both of these electrodes are used without any mediators, hence in the direct electron transfer mode.

\section{Studies of the electrodes in the fuel cell arrangement}

All of the carbon nanostructured electrodes tested: CP, CF and $\mathrm{CC}$ covered with enzymes were studied in the fuel cell environment. The system including Zn anode and MWCNTs cathode without any enzyme was also investigated to allow comparison. The Zn-MWCNTs fuel cell, Zn hybrid fuel cell and the fully enzymatic biofuel cell are presented in Scheme 1.

The characteristics of $\mathrm{Zn}$ anode-MWCNTs fuel cell, Zn hybrid fuel cell with laccase cathode and full biofuel cell with FDH based anode and laccase cathode are shown in Fig. 6.

The cell parameters for three supporting carbon materials on the cathode and $\mathrm{Zn}$ anode are collected in Table 1.

For comparison, the Zn-MWCNTs fuel cell without any enzyme is also included; however, its stability in time is worse.

The optimal support was found to be carbon paper CP, and this material was selected for the preparation of hybrid and full biofuel cells presented further (Fig. 6a, b). The maximum power for the $\mathrm{Zn}$ hybrid fuel cell is $1.65 \pm 0.21 \mathrm{~mW} \mathrm{~cm}{ }^{-2}$ $(5.18 \mathrm{~mW})$, and the open circuit potential is $1.7 \mathrm{~V}$. For a full biofuel cell with the laccase biocathode and fructose dehydrogenase bioanode, each of them covered with $2 \mathrm{mg}$ of
MWCNTs, the OCV value was $0.65 \pm 0.04 \mathrm{~V}$, and maximum power was $76 \pm 6 \mu \mathrm{W} \mathrm{cm} \mathrm{cm}^{-2}$. The aerated flowing solution contained $100 \mathrm{mM}$ fructose in Mcllvaine buffer, $\mathrm{pH}$ 5.3. In

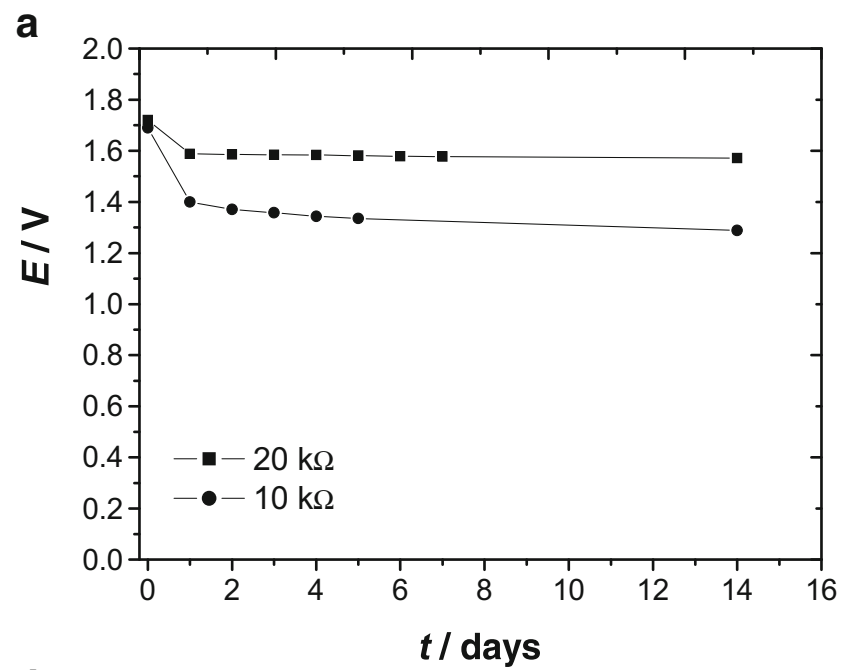

b

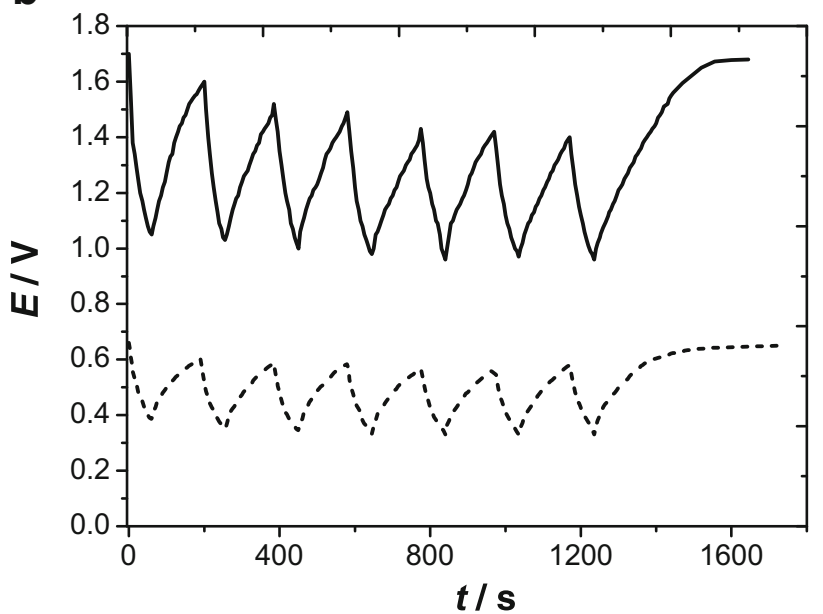

Fig. 7 (a) Potential-time dependencies for the Zn-hybrid fuel cell with laccase cathode under two external resistances: 20 and $10 \mathrm{k} \Omega$. (b) Potential-time dependence of a Zn-hybrid fuel cell with laccase cathode (solid line) and FDH/laccase biofuel cell (dotted line), "switched" on/off every $60 \mathrm{~s}$. External resistance applied to the circuit was $2 \mathrm{k} \Omega$. Experiments were conducted in aerated McIlvaine buffer solution $\mathrm{pH}$ 5.3, for biofuel cell-in the presence of $100 \mathrm{mM}$ fructose 
Fig. 6b, the current-voltage characteristics of the air-fructose biofuel cell is presented together with the power plot.

Potential-time dependences for the Zn-hybrid fuel cell with laccase cathode under two external resistances 20 and $10 \mathrm{k} \Omega$ are shown in Fig. 7a. After 15 days of continuous work, the potential of such Zn-hybrid biofuel cell stabilizes at a value equal to $92 \%$ of the initial value.

The voltage for the biofuel cell first decreases and then stabilizes at a value equal to $86 \%$ of the initial value. These cells were also tested in a pulsed regime: first the cell was discharged under $2 \mathrm{k} \Omega$ external resistance during $60 \mathrm{~s}$ and then the resistance was switched off and the fuel cell was left to regenerate (Fig. 7b). Sixty seconds time span is usually sufficient, e.g. for the sensor readout as shown elsewhere [32]. Following seven cycles of discharge/self-recharge, the cells were left to recharge fully to achieve the voltage corresponding to the OCV of each of the cells. In case of Zn hybrid fuel cell with laccase cathode, the time needed for full regeneration was $350 \mathrm{~s}$, while the biofuel cell required ca. $500 \mathrm{~s}$. In both cases, the open circuit potential is achieved confirming full self-regeneration of the devices.

\section{Conclusions}

Efficient and reproducible reduction of dioxygen catalyzed by laccase Trametes versicolor is obtained using carbon support materials: carbon paper, carbon fibre and carbon cloth. The materials can be soaked with carbon nanotubes under reduced pressure of the water pump leading to a stable nanostructured surface showing good affinity both for laccase and for fructose dehydrogenase. Adsorption of enzyme is improved when it is done from the McIlvaine buffer solution containing ethanolwater, ratio 1:1. Mediatorless oxygen reduction catalyzed by laccase proceeds close to the formal potential of laccase $\mathrm{T} 1$ site. The onset of catalytic curve of oxygen reduction was observed at the potential ca. $+0.6 \mathrm{~V}$ (vs. $\mathrm{Ag} / \mathrm{AgCl} / 1 \mathrm{M} \mathrm{KClaq}$ reference electrode) while the oxidation of fructose catalyzed by fructose dehydrogenase took place at ca. $-0.1 \mathrm{~V}$.

The design and construction of a $\mathrm{Zn}$ anode-MWCNTs cathode cell, Zn hybrid fuel cell with laccase cathode and full fructose dehydrogenase/laccase bioful cell were tested under flow of aerated solution. The maximum power densities 1.65 $\pm 0.21 \mathrm{~mW} \mathrm{~cm}^{-2}$ at $0.72 \mathrm{~V}$ and $76.5 \pm 6 \mu \mathrm{W} \mathrm{cm}{ }^{-2}$ at $0.31 \mathrm{~V}$ were obtained for modified carbon paper $\mathrm{Zn}$ hybrid cell and full biofuel cell, respectively. OCV for the biofuel cell was $0.68 \mathrm{~V}$. Full cell potential-time dependencies were monitored for 2 weeks and after $90 \mathrm{~min}$ in all cases potential was stabilized at $86 \%$ of the initial OCV value for each of the cells. The potential-time dependence for a $\mathrm{Zn}$ hybrid fuel cell with laccase CP cathode and full biofuel cell, being "switched" on/off every $60 \mathrm{~s}$ a time span sufficient for e.g. sensor readout, was recorded under external resistance $2 \mathrm{k} \Omega$ during discharging. Following seven cycles of discharge/recharge, the potential of each flow cell could be fully regenerated after not more than $500 \mathrm{~s}$ reaching the value of open circuit potential. The presented fuel cells, therefore, are designed to work under pulsed conditions useful, e.g. for powering sensing devices.

Acknowledgments This work was supported by FP7-People-2013ITN Grant "Bioenergy, Biofuel Cells: From fundamentals to application of bioelectrochemistry" under grant agreement no 607793. The biofuel cell part of this study was carried out at the Biological and Chemical Research Centre, University of Warsaw, established within the project co-financed by European Union from the European Regional Development Fund under the Operational Programme Innovative Economy, 2007-2013.

Open Access This article is distributed under the terms of the Creative Commons Attribution 4.0 International License (http:// creativecommons.org/licenses/by/4.0/), which permits unrestricted use, distribution, and reproduction in any medium, provided you give appropriate credit to the original author(s) and the source, provide a link to the Creative Commons license, and indicate if changes were made.

\section{References}

1. Zagal JH, Paez M, Tanaka AA, Dos Santos JR, Linkous CA (1992) Electrocatalytic activity of metal phthalocyanines for oxygen reduction. J Electroanal Chem 339:13-30

2. Zagal JH (2010) Metallophthalocyanines as catalysts in electrochemical reactions. Coord Chem Rev 254:2755-2791

3. Zagal JH, Griveau S, Ozoemena KI, Nyokong T, Bedioui F (2009) Carbon nanotubes, phthalocyanines and porphyrins: attractive hybrid materials for electrocatalysis and electroanalysis. J Nanosci Nanotechnol 9:2201-2214

4. Zagal JH, Recio FJ, Gutierrez CA, Zuñiga C, Páez MA (2014) Towards a unified way of comparing the electrocatalytic activity MN4 macrocyclic metal catalysts for $\mathrm{O}_{2}$ reduction on the basis of the reversible potential of the reaction. Electrochem Comm 41:24 26

5. Masa J, Ozoema K, Schuhmann W, Zagal JH (2012) Oxygen reduction reaction using $\mathrm{N}_{4}$-metallomacrocyclic catalysts: fundamentals on rational catalyst design. Journal of Porphyrins and Phthalocyanines 16:761-784

6. Bashuam R, Zelenay P (2006) A class of non-precious metal composite catalysts for fuel cells. Nature 443:63-66

7. Banham D, Ye S, Pei K, Ozaki J, Kishimoto T, Imashiro Y (2015) A review of the stability and durability of non-precious metal catalysts for the oxygen reduction reaction in proton exchange membrane fuel cells. J Power Sources 285:334-348

8. Mano N, Fernandez JL, Kim Y, Shin W, Bard AJ, Heller A (2003) Oxygen is electroreduced to water on a wired enzyme electrode at a lesser overpotential than on platinum. J Am Chem Soc 125:15290 15291

9. Blanford CF, Heath RS, Armstrong FA (2007) A stable electrode for high-potential, electrocatalytic $\mathrm{O}_{2}$ reduction based on rational attachment of a blue copper oxidase to a graphite surface. Chem Comm 17:1710-1712

10. Cracknell JA, Vincent KA, Armstrong FA (2008) Enzymes as working or inspirational electrocatalysts for fuel cells and electrolysis. Chem Rev 108:2439-2461

11. Dos Santos L, Climent V, Blanford CF, Armstrong FA (2010) Mechanistic studies of the 'blue' cu enzyme, bilirubin oxidase, as 
a highly efficient electrocatalyst for the oxygen reduction reaction. Phys Chem Chem Phys 12:13962-13974

12. Leger C, Bertrand P (2008) Direct electrochemistry of redox enzymes as a tool for mechanistic studies. Chem Rev 108:2379-2438

13. Kosman DJ (2010) Multicopper oxidases: a workshop on copper coordination chemistry, electron transfer, and metallophysiology. J Biol Inorg Chem 15:15-28

14. Solomon EI, Sundaram UM, Machonkin TE (1996) Multicopper oxidases and oxygenases. Chem Rev 96:2563-2606

15. Bilewicz R, Opallo M (2010) Biocathodes for dioxygen reduction in biofuel cells. In: Wieckowski A, Norskov JK (eds) Fuel cell science: theory, fundamentals and biocatalysis. John Wiley \& Sons, Hoboken, pp 169-214

16. Mano N, Edembe L (2013) Bilirubin oxidases in bioelectrochemistry: features and recent findings. Biosensors and Bioelectronics 50:478-485

17. Ulyanova Y, Babanova S, Pinchon E, Matanovic I, Singhal S, Atanassov P (2014) Effect of enzymatic orientation through the use of syringaldazine molecules on multiple multi-copper oxidase enzymes. Phys Chem Chem Phys 16:13367-13375

18. Leech D, Kavanagh P, Schuhmann W (2012) Enzymatic fuel cell: recent progress. Electrochim Acta 84:223-234

19. Spain C, Minteer SD (2008) Enzyme immobilization in biotechnology. Recent Pat Eng 2:195-200

20. Tortolini C, Rea S, Carota E, Cannistraro S, Mazzei F (2012) Influence of the immobilization procedures on the electroanalytical performances of Trametes versicolor laccase based bioelectrodevices. Microchem J 100:8-13

21. Lalaoui N, Elouarzaki K, Le Goff A, Holzinger M, Cosnier S (2013) Efficient direct oxygen reduction by laccases attached and oriented on pyrene-functionalized polypyrrole/carbon nanotube electrodes. Chem Commun 49:9281-9283

22. Shleev S, Tkac J, Christenson A, Ruzgas T, Yaropolov AI, Whittaker JW (2005) Direct electron transfer between coppercontaining proteins and electrodes. Biosens Bioelectron 20:25172554

23. Karaskiewicz M, Majdecka D, Więckowska A, Biernat JF, Rogalski J, Bilewicz R (2014) Induced-fit binding of laccase to gold and carbon electrodes for the biological fuel cell applications. Electrochim Acta 126:132-138

24. Shleev S, Wang Y, Gorbacheva M, Christenson A, Haltrich D, Ludwig R, Ruzgas T, Gorton L (2008) Direct heterogeneous electron transfer reactions of Bacillus halodurans bacterial blue multicopper oxidase. Electroanal 20:963-969

25. Falk M, Blum Z, Shleev S (2012) Direct electron transfer based enzymatic fuel cells. Electrochim Acta 82:191-202

26. Bourourou M, Elouarzaki K, Lalaoui N, Agnes C, Le Goff A, Holzinger M, Maaref A, Cosnier S (2013) Supramolecular Immobilization of Laccase on carbon nanotube electrodes functionalized with (methylpyrenylaminomethyl) anthraquinone for direct electron reduction of oxygen. Chem Eur J 19:9371-9375
27. Brocato S, Lau C, Atanassov P (2012) Mechanistic study of direct electron transfer in bilirubin oxidase. Electrochim Acta 61:44-49

28. Rozniecka E, Jonsson-Niedziolka M, Sobczak JW, Opallo M (2011) Mediatorless bioelectrocatalysis of dioxygen reduction at indium-doped tin oxide (ITO) and ITO nanoparticulate film electrodes. Electrochim Acta 56:8739-8745

29. Nazaruk E, Sadowska K, Biernat JF, Rogalski J, Ginalska G, Bilewicz R (2010) Enzymatic electrodes nanostructured with functionalized carbon nanotubes for biofuel cell applications. Anal Bioanal Chem 398:1651-1660

30. Stolarczyk K, Lyp D, Zelechowska K, Biernat JF, Rogalski J, Bilewicz R (2012) Arylated carbon nanotubes for biobatteries and biofuel cells. Electrochim Acta 79:74-81

31. Lalaoui N, Le Goff A, Holzinger M, Mermoux M, Cosnier S (2015) Wiring Laccase on covalently modified graphene: carbon nanotube assemblies for the direct bio-electrocatalytic reduction of oxygen. Chem Eur J 21:3198-3201

32. Pankratov DV, Zeifman YS, Morozova OV, Shumakovich GP, Vasil'eva IS, Shleev S, Popov VO, Yaropolov AI (2013) A comparative study of biocathodes based on multiwall carbon nanotube buckypapers modified with three different multicopper oxidases. Electroanalysis 25:1143-1149

33. Li Y, Huang X, Qu Y (2013) A strategy for efficient immobilization of laccase and horseradish peroxidase on single-walled carbon nanotubes. J Chem Technol Biotechnol 88:2227-2232

34. Papper V, Elouarzaki K, Gorgy K, Sukharaharja A, Cosnier S, Marks RS (2014) Biofunctionalization of multiwalled carbon nanotubes by electropolymerized poly(pyrrole-concavalin A) films. Chem Eur J 20:13561-13564

35. Scherbahn V, Putze MT, Dietzel B, Heinlein T, Schneider JJ, Lisdat F (2014) Biofuel cells based on direct enzyme-electrode contacts using PQQ-dependent glucose dehydrogenase/bilirubin oxidase and modified carbon nanotube materials. Biosens Bioelectron 61: 631-638

36. Pankratov D, Blum Z, Shleev S (2014) Hybrid electric power biodevices. Chem Electro Chem 1:1798-1807

37. Pankratov D, Falkman P, Blum Z, Shleev S (2014) A hybrid electric power device for simultaneous generation and storage of electric energy. Energy Environ Sci 7:989-993

38. Skunik-Nuckowska M, Grzejszczyk K, Stolarczyk K, Bilewicz R, Kulesza PJ (2014) Integration of supercapacitors with enzymatic biobatteries toward more effective pulse - powered use in smallscale energy harvesting devices. J Appl Electrochem 44:497-507

39. Agnes C, Holzinger M, Le Goff A, Reuillard B, Elouarzaki K, Tingry S, Cosnier S (2014) Supercapacitor/biofuel cell hybrids based on wired enzymes on carbon nanotube matrices: autonomous reloading after high power pulses in neutral buffered glucose solutions. Energy Environ Sci 7:1884-1888

40. Kizling M, Stolarczyk K, Sim Sin Kiat J, Tammela P, Wang Z, Nyholm L, Bilewicz R (2015) Pseudocapacitive polypyrrolenanocellulose composite for sugar-air enzymatic fuel cells. Electrochem Commun 50:55-59 